\title{
Correction to: MCL-1 inhibitors, fast-lane development of a new class of anti-cancer agents
}

Arnold Bolomsky ${ }^{1}$, Meike Vogler ${ }^{2}$, Murat Cem Köse ${ }^{3}$, Caroline A. Heckman ${ }^{4}$ Grégory Ehx ${ }^{3}$, Heinz Ludwig and Jo Caers ${ }^{3 *}$ (1)

Correction to: J Hematol Oncol (2020) 13:173 https://doi.org/10.1186/s13045-020-01007-9

The original article contains an incorrect affiliation for co-author, Meike Vogler. The correct affiliation can be viewed in this Correction article.

\footnotetext{
Author details

${ }^{1}$ Wilhelminen Cancer Research Institute, Wilhelminenspital, Vienna, Austria. ${ }^{2}$ Institute for Experimental Cancer Research in Pediatrics, Goethe-University, Frankfurt, Germany. ${ }^{3}$ Department of Clinical Hematology, GIGA-I3, University of Liège, CHU De Liège, 35, Dom Univ Sart Tilman B, 4000 Liège, Belgium. ${ }^{4}$ Institute for Molecular Medicine Finland-FIMM, HiLIFE-Helsinki Institute of Life Science, iCAN Digital Cancer Medicine Flagship, University of Helsinki, Helsinki, Finland.
}

Published online: 17 February 2021

\section{Reference}

1. Bolomsky A, et al. MCL-1 inhibitors, fast-lane development of a new class of anti-cancer agents. J Hematol Oncol. 2020;13:173. https://doi. org/10.1186/s13045-020-01007-9.

\section{Publisher's Note}

Springer Nature remains neutral with regard to jurisdictional claims in published maps and institutional affiliations. original author(s) and the source, provide a link to the Creative Commons licence, and indicate if changes were made. The images or other third party material in this article are included in the article's Creative Commons licence, unless indicated otherwise in a credit line to the material. If material is not included in the article's Creative Commons licence and your intended use is not permitted by statutory regulation or exceeds the permitted use, you will need to obtain permission directly from the copyright holder. To view a copy of this licence, visit http://creativecommons.org/licenses/by/4.0/. The Creative Commons Public Domain Dedication waiver (http://creativeco mmons.org/publicdomain/zero/1.0/) applies to the data made available in this article, unless otherwise stated in a credit line to the data. 